\title{
IMPROVING THE LEARNING MOTIVATION OF ELEMENTARY SCHOOL CHILDREN THROUGH TRADITIONAL GAMES IN FACING STAY-AT-HOME SITUATIONS
}

\author{
Muhardila Fauziah $^{1}$, Ade Eka Anggraini ${ }^{2}$, Yeni Sulaeman ${ }^{3}$, Lenni Marlina ${ }^{4}$ \\ ${ }^{1}$ Universitas PGRI Yogyakarta, Yogyakarta, Indonesia \\ ${ }^{2}$ Universitas Negeri Malang, Indonesia \\ ${ }^{3,4}$ STKIP Syekh Manshur \\ 1'dfausziah1988@gmail.com, 2ade.ekaanggraini.pasca@um.ac.id, 33yenisulaemananesta@gmail.com, \\ ${ }^{4}$ lennimarlina228@gmail.com
}

\begin{abstract}
The pandemic happened around the world has brought a major impact on the hfield of ealth and economy, as well as education. The government closed crowded places, offices, and schools. The school closures resulted in children in a situation called Stay At Home. The purpose of this research was to find out the efforts of parents and teachers in maintaining children's learning motivation at home, and the role of traditional games to increase children's learning motivation in facing Stay-At-Home situations. This research utilized a phenomenological approach with descriptive qualitative research. This research involved parents, teachers, and elementary school students in Solok. After approximately eight months, the schools as the research objects were closed so that students and teachers conducted learning from home. As a result, teachers, assisted by the guidance of parents, were demanded to create an active and creative atmosphere in teaching in order that students did not feel bored and learning objectives were achieved. One of the efforts was to encourage the children to play around the house so that the child did not feel bored. Traditional games were an effective alternative to minimaze the influence of gadgets.
\end{abstract}

Keywords: learning motivation, traditional games, stay at home

\section{MENINGKATKAN MOTIVASI BELAJAR ANAK SEKOLAH DASAR MELALUI PERMAINAN TRADISIONAL DALAM MENGHADAPI SITUASI STAY AT HOME}

\begin{abstract}
ABSTRAK
Pandemi besar yang terjadi di seluruh dunia mengakibatkan dampak besar pada bidang kesehatan dan ekonomi serta pendidikan. Pemerintahan menutup tempat keramaian, kantor-kantor, dan sekolah-sekolah. Penutupan sekolah mengakibatkan anak berada dalam situasi dan kondisi yang disebut Stay At Home. Tujuan penelitian ini yaitu untuk mengetahui bagaimana upaya orang tua dan guru dalam mempertahankan motivasi belajar anak di rumah, dan bagaimana peran permainan tradional untuk meningkatkan motivasi belajar anak dalam menghadapi situasi Stay At Home. Pendekatan penelitian ini menggunakan pendekatan fenomenalogi dengan jenis penelitian kualitatif deskriptif sebagai subjek penelitian yaitu orang tua, guru, dan siswa sekolah dasar di kota Solok. Setelah kurang lebih delapan bulan sekolah-sekolah sebagai objek penelitian ditutup sehingga siswa dan guru melakukan pembelajaran di rumah sehingga mengharuskan guru dengan bimbingan orang tua mampu menciptakan suasana yang aktif dan kreatif dalam mengajarkan siswa agar tidak merasa bosan dan tujuan pembelajaran tercai, salah satu upaya yang dilakukan yaitu tetap bermain di sekitar rumah sehingga anak merasa tidak bosan. Permainan tradisional menjadi alternatif yang efektif mengurangi pengaruh gadget.
\end{abstract}

Kata Kunci: motivasi belajar, permainan tradisional, stay at home

\begin{tabular}{|c|c|c|}
\hline Submitted & Accepted & Published \\
\hline 05 Maret 2021 & 10 April 2021 & 25 Mei 2021 \\
\hline
\end{tabular}

\begin{tabular}{|l|c|c|}
\hline Citation & $:$ & $\begin{array}{r}\text { Fauziah, M., Anggraini, A.E., Sulaeman, Y., \& Marlina, L. (2021). Improving the Learning Motivation of Elementary } \\
\text { School Children through Traditional Games in Facing Stay-At-Home Situations. Jurnal PAJAR (Pendidikan dan } \\
\text { Pengajaran), 5(3), 757-764. DOI : http://dx.doi.org/10.33578/pjr.v5i3.8289. }\end{array}$ \\
\hline
\end{tabular}

\section{PENDAHULUAN}

Awal bulan Maret 2020 ditemukan warga Indonesia yang positif covid19 yang disebut dengan penyakit corona. Penyakit corona pertama kali menimpa negara China kota Wuhan pada 
akhir tahun 2019. (Organization, 2020) Virus ini dapat ditularkan dari manusia ke manusia dan telah menyebar secara luas di China dan lebih dari 190 negara dan teritori lainnya. Pada 12 Maret 2020, WHO mengumumkan COVID-19 sebagai pandemik. Hingga tanggal 29 Maret 2020, terdapat 634.835 kasus dan 33.106 jumlah kematian di seluruh dunia. Sementara di Indonesia sudah ditetapkan 1.528 kasus dengan positif COVID-19 dan 136 kasus kematian. Dahsyatnya penyebaran penyakit ini maka pemerintah Indonesia dengan cepat tanggap melakukan pencegahan dengan menutup tempat umum, wisata, tranpotasi massal, serta sekolah-sekolah sebelum akhirnya pada akhir maret 2020 dilakukan lockdown dengan menutup seluruh instansi dan lembaga yang mengakibatkan berkumpulnya orang-orang.

Penutupan sekolah pada awalnya hanya dua minggu. Aktivitas belajar anak dilakukan di rumah dengan diberikannya tugas oleh guru disekolah dan melaporkannya via whatsapp atau email. Namun hal tersebut tidaklah maksimal dapat membuat anak merasa nyaman belajar di rumah. Dua minggu berlalu namun kegiatan belajar di rumah diperpanjang terus menerus karena meningkatnya penularan covid19 disetiap daerah di Indonesia. Penutupan sekolah itu menjadi tidak jelas sampai kapan. Hal tersebut mengakibatkan khususnya anak sekolah dasar mulai bosan dengan keberadaannya hanya berada di dalam rumah. Keberadaan di rumah merupakan bentuk himbauan kebijakan yang disebut dengan Stay At home (Siahaan, 2020). Keberadaan anakanak di rumah untuk belajar merupakan cara meminimalkan penyebaran covid19. Padahal kelemahan dari kebijakan tersebut adalah pekerjaan orang tua yang masih mengharuskannya keluar rumah dan berkemungkinan membawa virus tersebut.

Menurut (Jamal, 2020; Tabi, 2020) menjelaskan bahwa situasi Stay at Home mengakibatkan dampak yang berbeda-beda pada anak. Ada dampak positif dan ada dampak negatif. damapk positifnya adalah anak memiliki resiko lebih rendah terinfeksi virus, aktifitas anak terkontrol, orang tua dan anak dapat menjalin hubungan lebih dekat karena hampir 24 jam bersama, dan kesehatan anak dipastikan sangat baik. Selanjutnya dampak negatifnya anak terlalu lama dengan televisi, anak menjadi bosan (tidak kreatif) hanya tiduran saja, selalu menggunakan hp/gadget (bermain game online), dan kurang bersosialisasi dengan lingkungan.

Berdasarkan obeservasi yang dilakukan rendahnya motivasi disebabkan oleh kurang efektifnya pendekatan dan metode pembelajaran yang digunakan oleh guru dan orang tua. Selainitu siswa berangapan bahwa mereka libur panjang mereka hanya di rumah dan tidak ada aktivitas lain di luar rumah mereka mulai mengeluhkan tentang keberadaannya. Bahkan motivasi belajar mulai menurun karena mereka berpikir bahwa tugastugas yang diberikan oleh sekolah menjadi mudah karena bantuan dari orang tua dan waktu penyelesaian tugas tersebut tidak efektif terkadang guru terlalu sedikit memberikan tugaas dan terkadang banyak. Selain itu orang tua bahkan memudahkan penyelesaiannya dengan mengerjakannya sendiri tugas anak.

Motivasi merupakan keinginan yang dating dari diri seseorang secara tidak sadar mengaktifkan, menggerakkan, dan menyalurkan serta mengarahkan sikap untuk belajar (Pratama et al., 2019; Syafatania \& Widayat, 2016). Selanjutnya motivasi menjadi kekuatan atau dorongan dalam diri individu sehingga individu tersebut bergerak, bertindak untuk memenuhi kebutuhan dan mencapai tujuannya.

Rendahnya motivasi siswa belajar membuat orang tua berpendapat bahwa anak mereka menjadi hilang kreativitas bahkan mereka sendiri bingung dengan cara belajar anak. Bahkan mereka berpikir bahwa sebaiknya anak mereka ke sekolah saja karena daerah penulis merupakan daerah zona hijau. Untuk itu kejenuhan anak mulai dikurangi dengan mengijinkannya bermain hanya dengan teman-teman yang ada di sekitar rumah atau lingkungan. Alternatif yang penulis berikan pada beberapa lingkungan yaitu memulai kegiatan diluar rumah dengan tetap memperhatikan protokol yang sudah ditetapkan agar motivasi anak tetap stabil karena sudah satu bulan bahkan mungkin lebih berada di rumah diharapkan dengan melakukan permainan tradisional mereka mampu menghadapi situasi Stay at Home 
Kegiatan di luar rumah diharapkan dapat mengurangi kejenuhan dan tetap mengasah karakteristik sosial anak. Kegiatan tersebut diharapkan dapat mempertahankan motivasi belajar anak di rumah dan peran permainan tradisional dalam meningkatkan motivasi belajar anak menghadapi situasi Stay At Home. Motivasi adalah bentuk dorongan, gairah dan semangat yang timbul dari dalam diri sendiri maupun berkat dorongan lingkungan. Data akan penulis peroleh melalui observasi dan wawancara dengan subjek penelitian yaitu orang tua, guru, dan anak yang berada di daerah lingkungan penulis.

Berdasarkan permasalahan dan observasi dari orang tua dan siswa penulis melakukan penelitian tentang meningkatkan motivasi belajar siswa sekolah dasar melalui permainan tradisional dalam menghadapi situasi stay at home. Penelitian ini bertujuan untuk mengetahui bagaimana motivasi belajar siswa sekolah selama menghadapi situasi Stay at home, dan apakah permainan tradisional mampu meningkatkan motivasi belajar siswa.

\section{KAJIAN TEORI}

\section{Motivasi Belajar}

Motivasi memiliki peran penting dalam kemajuan dan prestaasi belajar siswa. Siswa yang memiliki motivasi tinggi berkemungkinan akan berhasil dalam proses pembelajaran sehingga mendapatkan nilai yang tinggi. Motivasi seseorang semakin meningkat maka usaha yang dilakukan juga akan berpengaruh terhadap keberhasilan dalam tujuan khusunya bagi siswa yaitu belajar. Motivasi menjadi salah satu faktor perubahan energi dalam diri seseorang yang ditandai dengan munculnya "feeling" dan didahului dengan tanggapan terhadap adanya tujuan" (Sardiman, 2011; Uno, 2009).

Motivasi membentuk kondisi khusus yang mempengaruhi individu untuk belajar dengan factor psikis yang bersifat non-intelektual. Pembelajaran tanpa adanya motivasi akan sangat sulit untuk berhasil (Fajriah et al., 2020; Sardiman, 2016). Sebab sktivitas belajar tidak mungkin dilakukan tanpa adanya tujuan yang ingin dicapai.

Motivasi merupakan faktor penting yang mempengaruhi peningkatan keterampilan menulis pantun. Penelitian yang dilakukan oleh Koca menyatakan motivasi untuk belajar mengacu pada kompetensi yang diperoleh melalui pengalaman umum yang sebagian besar distimulasi melalui pemodelan, komunikasi harapan, dan instruksi langsung atau sosialisasi signifikan yang dilakukan oleh orang lain, (Helda et al., 2020; Koca, 2016).

Berdasarkan pendapat di atas motivasi menjadi suatu dorongan yang mendalam berada dalam setiap diri dimana dorongan tersebut ada karena ingin mencapai suatu tujuan atau kebutuhan. Sehingga didalam motivasi pastilah seseorang memiliki tujuan.

\section{Permainan Tradisional}

Permainan tradisional berasal dari kata permainan dan tradisional. Permainan berarti sesuatu atau barang yang dipakai untuk bermain, sedangkan tradisional yaitu perilaku, cara berpikir, dan berbuat sesuatu yang selalu berpedoman pada norma dan adat istiadat yang ada secara turuntemurun. Permainan tradisional mempunyai nilai yang besar untuk generasi penerus bangsa dalam rangka berkreasi, berimajinasi, dan media untuk berlatih hidup bermasyarakat. Anak-anak zaman sekarang sudah tidak mengenal permainan tradisional karena mereka lebih tertarik dengan gadget dan/atau permainan modern.

Pada permainan tradisional anak-anak akan melakukan aktivitas sehingga aktivitas psikomotor, afektif, dan kognitifnya akan berkembang. Seperti yang dikemukakan oleh (Azizah, 2016; Fauziah et al., 2019; Ulya, 2017)permainan tradisional akan meningkatkan keterampilan dan kecekatan kaki dan tangannya, menggunakan kekuatan tubuhnya, ketajaman penglihatannya, kecerdasan pikirannya, keluwesan gerak tubuhnya, menirukan alam lingkungannya.

\section{METODE PENELITIAN}

Jenis Penelitian ini kualitatif dengan pendekatan fenomenologi Penelitian fenomenologi mencoba menjelaskan atau mengungkap makna konsep atau fenomena pengalaman yang didasari oleh kesadaran yang terjadi pada beberapa individu. Menurut (Creswell, 1998; Sugiyono, 
2015), Pendekatan fenomenologi menunda semua penilaian tentang sikap yang alami sampai ditemukan dasar tertentu. Pemilihaan mempertimbangkan akibat pandemi dunia, dan pertimbangan khusus di daerah peneliti yaitu Pertama; dengan fenomenologi memungkinkan untuk mengetahui esensi permainan tradisional dalam meningkatkan motivasi kegiatan belajara anak di rumah selama covid19. Kedua; dengan menggunakan metodologi kualitatif fenomenologi diharapkan dapat mengungkapkan kondisi psikologis anak yang selama menghadapi situasi Stay at Home dengan permainan tradisional. Penelitian ini difokuskan kepada anak usia sekolah dasar. Observasi awal tentang yang dilakukan mengamati kegiatan belajar selama di rumah, serta bagaimana menjaga kestabilan motivasi anak.

Dalam hal ini, partisipan merupakan siswa sekolah dasar di Kota Solok. Adapun prosedur penyampelan dalam penelitian ini menggunakan Teknik Purposive Sampling, sebagai subjek partisipan dalam penelitian ini adalah anak usia sekolah dasar dengan jumlah sampel masingmasing 5-10 orang yang intensitas waktu berada di rumah. anak usia sekolah dasar yang dilibatkan dari tiga Kelurahan di Kota Solok. Pemilihan lokasi penelitian dengan mempertimbangkan kemudahan dalam penyebaran angket sehingga dengan cepat dapat dikembalikan oleh responden. Waktu penelitian yang dilakukan mulai dari analisis semenjak Maret 2020 sampai Juni 2020 (kurang lebih empat bulan) situasi Stay at Home yang dialami anak. Anak yang diminta untuk mengisi angket terlebih dahulu dimintai kesediaannya secara personal oleh peneliti.

Instrumen yang digunakan dalam penelitian ini terdiri dari Lembar wawancara dan Angket. Sebelum menyebarkan kuesioner, dilakukan proses validasi ahli kepada dosen yang ahli dalam bidang evaluasi dan perkembangan anak , proses validasi ini bertujuan untuk mendapatkan kuesioner yang dapat digunakan untuk mengumpulkan data seperti tujuan penelitian. Begitu juga dengan pedoman wawancara dilakukan validasi oleh ahli. Setelah divalidasi maka lembar angket akan disebarkan pada orang tua, guru, dan anak.

\section{HASIL DAN PEMBAHASAN}

Keadaan masyarakat seluruh dunia dalam menghadapi covid19 telah melumpuhkan berbagai sekotor termaksuk pendidikan. Pendidikan khususnya sekolah dasar mempengaruhi sangat signifikan dimana anak-anak pada usia sekolah dasar memasuki tahapan pertumbuhan. Untuk anak usia sekolah dasar mereka membutuhkan pembelajaran yang kongkret. Dimana mereka perlu mengalami sendiri setiap makna dari tema pembelajaran agar mereka memiliki pengalaman belajar yang sangat baik dan luas.

Pandemi covid19 di berbagai daerah memberikan dampak yang sangat besar dimana anak yang biasanya perkgi seklah sekarang hanya berada di rumah dan mereka yang biasanya bermain sekarang hanya duduk dan sibuk dengan televisi atau gadget/hp saja. Dunia mereka dipenuhi dengan tegnologi digital yang terkadang tidak terkontrol oleh orang tua karena mereka memiliki masing-masing hp/gadget.

Hasil analisis data yang penullis kumpulkan terhadap subjek penelitian menunjukan beberapa data yang sangat menarik yang memberikan dampak positif dan negatif bagi perkembangan sosial dan motivasi belajar anak selama pandemi covid19. Data tersebut menunjukan sebagai berikut:

\section{Upaya orang tua dan guru meningkatkan motivasi anak selama stay at home}

Kegiatan yang dilakukan orang tua selama pandemi covid19 dengan keberadaan di rumah setiap hari. Orang tua dilingkungan penelitian memiliki pekerjaan yang bermacam-macam. Pekerjaan yang dilakoni oleh orang tua dan bentuk kegiatan yang dilakukan akan penulis kelompokan dalam beberapa profesi, diantaranya:

a. Pegawai negeri sipil (PNS)/Honorer

Orang tua yang orang tuanya bekerja pada intansi pemerintah merupakan orang tua yang sangat berdampak terhadap pandemi covid19 ini karena mereka yang rutinitasnya setiap hari kerja (senin-jumat) selalu berada diluar rumah selama masa covid19 mereka sekarang duduk di rumah. Orang tua tersebut memiliki banyak keluhan terhadap situasi stay at home.

Berdasarkan hasil observasi dan wawancara yang penulis lakukan ditemukan 
bahwa mereka merasakan dampak covid19 ini membuat mereka mengetahui karakter anaknya masing-masing. Orang tua merasa anak-anaknya pada minggu pertama dan kedua menikmati libur atau kegiatan belajar di rumah, namun pada minggu ke tiga dan sampai sekarang anak-anak mereka menjadi jenuh. Anak-anak sibuk dengan gadget, pengeluaran untuk kuota menjadi meningkat, tugas anak menjadi tidak selesai karena orang tua juga harus menyelesaikan tugasnyaa yang diberikan kantor. Kegiatan orang tua selama di rumah menjadi berlipat-lipat, diantaranya mereka harus masak, menjaga anak, pekerjaan masih tetap harus diselesaikan, dan kegiatan libur tidak ada.

\section{b. Petani}

Bagi orang tuanya yang petani juga berdampak bukan karena aktifitas/rutinitas untuk kesawah tetapi mereka berasusmsi bahwa biasanya mereka menyerahkan anak mereka ke sekolah untuk diajarkan karena mereka ada yang tidak tahu tentang pembelajaran (hanya tamatan SD/SMP) dan ada yang bingung harus berbuat apa jika anaknya tinggal di rumah dan dia pergi ke sawah. Kendala lain yang terjadi pada orang tua yang berpofesi sebagai petani yaitu waktu untuk mengumpulkan tugas anaknya dan mengontrol kegiatan anaknya tidaklah semaksimal orang tua yang stay di rumah untuk memberikan tugas kepada guru.

\section{c. Pedagang}

Situasi stay at home bagi para pedagang juga berdampak pada sepinya pemasukan orang tua, hal tersebut masih dapat mengkondisikan keberadaan orang tua dan membantu anak untuk belajar di rumah. Karena selama masa pandemi para pedagang dibatasi waktu untuk membuka tokonya. Selain itu orang tua yang kerjanya berdagang masih mampu menyikapi waktu bersama anak. Namun keluhan orang tua yaitu anak mulai bosan dengan rutinitas dan kurang bermain dengan teman-temannya

\section{d. Ibu Rumah Tangga}

Tanggapan ibu-ibu rumah tangga dengan adanya pandemi ini mereka hanya tidak mampu dengan tingkah anaknya yang mungkin biasanya saat mereka kesekolah rumah menjadi tenang dan ia dapat mengerjakan segala pekerjaan rumah dengan maksimal. Namun semenjak covid pekerjaan rumah terasa tidak habis-habisnya terselesaikan. Pengeluaran rumah menjadi meningkat, sementara penghasilan mereka berkurang. Didalam rumah rering terjadi keributan atau pertengkaran anatara anak-mereka dan orang tua berksimpulan kondisi ini tidak membuat mereka terserang virus korona tetapi membuat mereka menjadi stress.

\section{Pengaruh permainan tradisional dalam mengisi waktu selama stay at home}

Setelah lebih dari dua minggu para orang tua pada perumahan komplek dan lingkungan kampung yang sudah diseterilkan perkelurahan oleh pemerintah kota mulai memberikan kesempatan pada anak untuk bermain di luar rumah dengan protokol yang telah di tetapkan yaitu menggunakan masker, dan mencuci tangan sebelum dan sehabis bermain. Saat kembali masuk kerumah mereka harus mandi. Kesempatan bermain dimulai setelah sholat azhar hingga sebelum magrib.

Berdasarkan hasil pengamataan penulis dan wawancara penulis temukan bahwa mereka bermain permaianan yang sering dimainkan anakanak di daerah secara turun temurun (permainan tradisional). Pemilihaan permainan ini dikarenakan area perumahan masih memiliki ruang hijau sehingga anak-anak masih dapat memanfaatkannya. Permaianan tradisional dapat menumbuhkan dan mengasah karakteristik kerjasama, sosial, dan sportifitas anak. Permainan tradisional yang sering mereka mainkan adalah permainan yang berkelompok, setiap kelompok terdiri dari minimal 3 orang jadi saat bermain disore hari anak-anak merasa senang dan bahagia. Saat kembali kerumah maka akan ada pengalaman baru yang tidak jauh berbeda dari kegiatan bermainan mereka di sekolah. Orang tua merasa senang dan anak menjadi termotivasi untuk melakukan kegiatan yang telah dijadwalkan baik dari guru di sekolah maupun oleh orangtuanya untuk dapat bermainan di sore hari. 


\section{Permainan tradisional mampu meningkatkan motivasi anak selama stay at home}

Tujuan penelitian ini ingin mengetahui apakah permainann tradisional mampu meningkatkan motivasi anak selama situasi stay at home. Berdasarkan hasil angket observasi yang penulis sebarkan dapat disimpulkan dikemukakan data yaitu: $93.3 \%$ orang tua (28 dari 30 orang) mengatakan bahwa anak mereka mulai disiplin dalam mengerjakan tugas yang diberikan sekolah dengan mandiri mengerjakan. Anak-anak mulai aktif kembali karena pada usia mereka ini perkembangan psikomotnya juga perlu diasah (kegiatan olah raga) melalui gerak aktif anggota tubuh.

Motivasi anak untuk membali nan menanti kegiatan dan aktivitas belajar di sekolah ditunggutunggu. Keinginan bertemu teman-teman sekolah dan melakukan permainan tradisional lebih menyenangkan jika anggota pemaain menjadi lebih banyak. Keinginan/antusias anak menceritakan pengalamaan selama libur kepada guru dan teman-teman sangat tinggi

\section{Pembahasan}

1. Upaya orang tua dan guru dalam mempertahankan motivasi belajar anak di rumah

Dampak covid19 sangatlah besar dalam sektor ekonomi, sosial, dan pendidikan. Semua sarana umum ditutup. Fasilitas tranportasi dibatasi seminimal mungkin bahkan hampir tidak ada layangan tranportasi umum. Instansi-instasi serta lembaga-lembaga pemerintah dan swasta mengalami gejolak. Mayarakat dengan ekonomi rendah semakin terpuruk.

Pendidikan merupakan salah satu tolak ukur pertahanan negara untuk masa depan. untuk menciptakan genarasi yang berkualitas dan berkempuan profesional di masa depan dipengaruhi oleh tingkat pendidikan saat sekarang ini. namun apa yang terjadi akibat covid19 lembaga pendidikan negeri maupun swasta harus ditutup dalam jangka waktu yang tidak dapat dipastikan. Tutupnya lembaga pendidikan yaitu sekolah bukan berarti bebas dari aktivitas kegiatan pembelajaran makasunya pembelajaran dilakukan dari rumah dengan bimbingan dari orang tua di rumah.

Awal pembelajaran dirumah dianggap sebagai libur bagi anak sehingga anak-anak merasa senang dan bahagia. Namun setelah dua minggu berlalu mereka mulai merasa bosan dengan tugas yang diberikan dan keterbatasan mereka berada diluar rumah membuat mereka merasa terkekang. Peristiwa tersebut mengakibatkan motivasi anak untuk mengerjakan tugas dari guru mulai menurun.

Berdasarkan data yang penulis peroleh dari guru tugas anak menjadi sulit untuk diukur, kemaampuan anak tidak dapat dibuktikan dengan baik. Dilihat dari hasil belajar anak, $45 \%$ anak memperoleh nilai di bawah kriteria ketuntasan minimum. Hasil tersebut dierkuat oleh penelitian yang dilakukan oleh (Tabi, 2020; Widhiastuti, 2013) Guru memperkirakan hal tersebut dikarenakan beberapa faktor diantaranya: orang tua yang mungkin tidak mengoreksi tugas anak sebelum dikirimkan ke guru melalui WA/Email; beberapa anak berasal dari ekonomi yang rendah sehingga tugas yang diberikan tidak sampai dan akhirnya tidak dikumpulkan; latar pendidikan orang tua yang rendah; dan kesibukan orang tua di rumah.

Selanjutnya menurut orang tua, anak-anak mereka selama libur pandemi covid19 ini menjadi dua kelompok, kelompok pertama orang tuanya mengatakan bahawa anak mereka mulai malas; susah diatur; sibuk dengan gadget/hp; dan mereka memiliki pengeluaran tambahan (kuota Internet). Kelompok kedua orang tua mengatakan bahwa anak mereka memiliki waktu istirahat yang cukup; mereka sering berbagi tugas; anaknya disiplin dalam mengerjakan sholat lima waktu; dan semua tugas rumah anak-anak dapat membantu.

Namun dalam pengumpulan data orang tua dan guru memiliki perbedaan dalam menjaga motivasi anak. Dimana guru berusaha memberikan tugas sedikit agar tidak membebani anak dan orang tua di rumah sehingga proses pembelajaran tetap berlangsung walaupun tidak seefektif di sekolah.

Sedangkan orang tua untuk menjaga motivasi anak memberikan reword terhadap setiap tugas yang dikerjakan anak secara disiplin dan bertanggung jawab. Reword yang diberikan orang tua sebelumnya didiskusikan dengan anak agar 
reword tersebut tidak membuat anak manja. Salah satu bentuk reword yang diberikan orang tua adalah reward keluar rumah untuk bermain ini sangat banyak dipilih oleh anak-anak sebagai imbalan atas tugas yang telah dikerjakan karena rindunya anak untuk bermain dan bermain dengan teman-temannya menjadi lebih menarik bagi anak dibanding reword lainnya.

Berdasarkan diskusi penulis dengan guru dan orang tua disimpulkan bahwa guru mendukung keinginan anak untuk bermain diluar rumah karena berpengaruh pada kesehatan mata, pikiran, sosial anak. Sedangkan orang tua merassa bersyukur dengan keinginan anak karena jika anak meminta dibelikan ini dan itu maka akan ada pengeluaran tambahan bagi orang tua dan pemasukan mereka sendiri sudah sangat rendah.

\section{Peran permainan tradisional untuk meningkatkan motivasi belajar anak dalam menghadapi situasi Stay At Home.}

Berlandasan dari upaya yang dilakukan guru dan orang tua diatas selama empat bulan penulis berada dilingkungan observasi penulis anak-anak mulai beraktivitas diluar rumah seperti biasanya setelah sholat dzuhur. Ternyata itu merupakan reword atau permintaan anak setelah mereka jenuh dengan keberadaan mereka di dalam rumah.

Kegiatan mereka di luar rumah selama pengamatan penulis mereka bermain engkek (lore dalam bahasa minang), lompat tali, sepak tekong, benteng-benteng, dan petak umpet. Permainan tersebut merupakan permainan yang dimainkan secara turun temurun di daerah yang disebut dengan permainan tradisional. Kegiatan bermain diluar rumah akan melatih rileksasi mata anak, anggota tubuh, dan sosial anak. Permainanpermaian yang dipilih dan dimainkan itu memiliki filosofi yang sangat baik. Diantaranya dalam permainan tersebut muncul pembentukan karakter anak yaitu kerjasama, sportifitas, kesabaran, tenggang rasa, saling berbagi, tanggungjawab, tolong menolong, dan sosial. Selain itu permaianan ini anak meningkatkan imunitas anak yang dibutuhkan dalam mempertahankan kesehatan dimasa covid19.
Menurut orang tua bahwa dengan kesempatan bermain dan tetap mematuhi protokol yang diberikan pemerintah anak-anak mereka terjaga motivasi mereka untuk kembali ke sekolah. Hal tersebut mejadi pertanyaan mereka setiap saat kapan mereka belajar dan bertemu dengan temanteman sekolah. Selain itu situasi stay at home akan meningkatkan komunikasi antara orang tua dan anak (Widhiastuti, 2013).

\section{SIMPULAN DAN REKOMENDASI}

Kesimpulan hasil penelitian yang penulis lakukan sebagai berikut. 1) Orang tua menciptakan suasana belajar yang menarik berupa pemberian reword kepada anak jika anak mengerjaakan tugas yang dibeikan guru tepat waktu tanpa diperintahakan. Selain itu, orang tua selama masa pandemi memiliki keterikatan emasional yang sangat baik dengan anak karena interaksi mereka hampir 24 jam bersala di rumah; 2) Guru memberikan tugas kepada anak sebagaimana jadwal belajar sekolah, dan tugas dikumpulkan secara daring melalui WA/email berupa foto tugas yang diberikan dan kegiatan yang dilakukan selama berada dirumah yang dilaporkan oleh orang tua hal tersebut merupakan bentuk kontrol orang tua terhadap kegiatan anak selama stay at home; 3) Anak bermain diluar rumah selepas azhar dengan teman-teman dilingkungannya untuk menjaga motivasi menghilangkan kejenuhaan mereka setelah sebulan mereka tidak keluar rumah. Permainan yang mereka lakukan yaitu sepakbola, kasti, layang-layang, engklak, kelereng (gundu), asin, dan beberapa permainan lainnya.

Sebagaimana penelitian yang penulis lakukan maka diharapkan peran aktif orang tua dalam menjadi motivasi belajar siswa dan guru untuk dapat memberikan tugas yang tidak hanya bersifat dengan tuntutan mengukur kognitif siswa juga mengajak siswa untuk berbuat sesuatu yang menyenangkan sehingga didalammelaksanakan tugas dan pembelajaran siswa tidak jenuh dan selalu berantusia menunggu tugas yang akan diberikan guru setiap harinya.

\section{DAFTAR PUSTAKA}

Azizah, I. M. (2016). Efektivitas Pembelajaran Menggunakan Permainan Tradisional 
Terhadap Motivasi Dan Hasil Belajar Materi Gaya Di Kelas Iv Min Ngronggot Nganjuk. Dinamika Penelitian, 16(2), 279-308.

Creswell, J. W. (1998). Qualitative Inquiry and Research Design: Choosing Amang Five Tradition. Sage Publications.

Fajriah, Z. N., Pipit, M., \& Atabik. (2020). The Impact Of Zoning Systems On Students Motivation In Smpn 1 Majenang. Jurnal PAJAR ( Pendidikan Dan Pengajaran ), 4(5), 1070-1080.

Fauziah, M., AE Anggraini, T., Rahman, Sulaeman, Y., \& Kharisma, A. (2019). Game "Sepak Tekong" As A Method for Increasing the Ability of Reading Situation in Primary School. INCOLWIS 2019: Proceedings of the 2nd International Conference on Local Wisdom, INCOLWIS 2019, August 29-30, 2019, Padang, West Sumatera, Indonesia, 480.

Helda, R. A., Mardiah, H., \& R, S. (2020). The Influence Of Contextual Teaching And Learning Approach And Learning Motivation Toward Writing Skills Of Pantun In The Fifth Grade Students Of Elementary School. Jurnal PAJAR (Pendidikan Dan Pengajaran), 4(4), 812-818.

Jamal, S. (2020). Analisis Kesiapan Pembelajaran E-Learning Saat Pandemi Covid-19 Di Smk Negeri 1 Tambelangan. Jurnal Nalar Pendidikan, $8(1), \quad 16$. https://doi.org/10.26858/jnp.v8i1.13561

Koca, F. (2016). Motivation to Learn and TeacherStudent Relationship. Journal of International Education and Leadership, 6(2).

Organization, W. (World H. (2020). Corona Disese 2019 (covid-19) Situastion Report. 30 Maret 2020.

Pratama, F., Firman, \& Neviyarni. (2019). Pengaruh Motivasi Belajar Ipa Siswa Terhadap Hasil. Jurnal Ilmu Pendidikan, 1(3), 280-286. https://edukatif.org/index.php/edukatif/index $\% 0 A P E N G A R U H$

Sardiman. (2016). Interaksi \& Motivasi Belajar Mengajar (1st ed.). Rajawali Pers.

Sardiman, A. M. (2011). Interaksi dan Motivasi Belajar Mengajar. PT Raja Grafindo Persad.
Siahaan, M. (2020). Dampak Pandemi Covid-19 Terhadap Dunia Pendidikan. Jurnal Kajian Ilmiah, 1(1), 73-80. https://doi.org/10.31599/jki.v1i1.265

Sugiyono. (2015). Metode Penelitian Kuantitatif Kualitatif dan $R \& D$. Alfabeta.

Syafatania, \& Widayat, I. W. (2016). Strategi Orang Tua dalam Mengoptimalkan Potensi Seni Anak Berbakat Istimewa. Jurnal Psikologi Pendidikan Dan Perkembangan Vol, 5(1), 1-15.

Tabi, A. (2020). Problematika Stay At Home Pada Anak Usia Dini Di Tengah Pandemi Covid 19. Jurnal Golden Age, 4(01), 190-200. https://doi.org/10.29408/jga.v4i01.2244

Ulya, H. (2017). Permainan tradisional sebagai media dalam pembelajaran matematika. Prosiding Seminar Nasional Pendidikan, 6(11), 371-376. http://repository.ummetro.ac.id/files/semnasd ik/967b29a8033b7621321b15c78166e74a.pd $\mathrm{f}$

Uno, H. . (2009). Teori motivasi dan Pengukurannya (Analisis di Bidang Pendidikan). BUMI AKSARA.

Widhiastuti, C. \& M. D. Y. H. N. (2013). Peranan Stay at Home Dad dalam Membentuk Keluarga Sehat dan Harmonis. Psibernetika, $6(2), 59-73$. 